\title{
Elevated Farnesoid X Receptor (FXR) and Retinoid X Receptors (RXRs) expression is associated with less tumor aggressiveness and favourable prognosis in patients with pancreatic adenocarcinoma
}

\author{
C. GIAGINIS ${ }^{1,2 *}$, I. KOUTSOUNAS ${ }^{1}$, P. ALEXANDROU ${ }^{1}$, A. ZIZI-SERBETZOGLOU ${ }^{3}$, E. PATSOURIS ${ }^{1}$, G. KOURAKLIS ${ }^{4}$, S. THEOCHARIS ${ }^{1}$
}

${ }^{1}$ First Department of Pathology, Medical School, National and Kapodistrian University of Athens, Athens, Greece; ${ }^{2}$ Department of Food Science and Nutrition, School of the Environment, University of the Aegean, Myrina, Lemnos, Greece; ${ }^{3}$ Department of Pathology, Tzaneio General Hospital, Piraeus, Greece; ${ }^{4}$ Second Department of Propedeutic Surgery, Medical School, University of Athens, Athens, Greece

${ }^{*}$ Correspondence: cgiaginis@aegean.gr

Received July 3, 2014 / Accepted October 16, 2014

\begin{abstract}
Farnesoid X Receptor (FXR) and its co-partners Retinoid X Receptors (RXRs) are considered to participate in crucial biochemical and cellular processes, being involved in the pathogenesis of several diseases, including cancer. The present study aimed to evaluate the clinical significance of FXR alone and in conjunction with RXRs expression, in pancreatic adenocarcinoma. FXR, RXR- $\alpha,-\beta$ and $-\gamma$ protein expression was assessed immunohistochemically on tumoral samples of 55 pancreatic adenocarcinoma cases and was statistically analyzed with clinicopathological characteristics, tumor proliferative capacity and patients' survival. Enhanced FXR expression was borderline associated with earlier histopathological stage $(\mathrm{p}=0.054)$. Concomitant elevated FXR/RXR- $\alpha$ expression was significantly associated with decreased tumor histological grade ( $\mathrm{p}=0.017$ ), while concomitant enhanced FXR/RXR- $\beta$ and FXR/RXR- $\gamma$ expression with earlier histopathological stage $(\mathrm{p}=0.017$ and $\mathrm{p}=0.004$, respectively) and smaller tumor size $(\mathrm{p}=0.037$ and $\mathrm{p}=0.005$, respectively). Concomitant enhanced FXR/RXR- $\gamma$ expression was additionally significantly associated with the absence of lymph node metastases $(\mathrm{p}=0.018)$. Pancreatic adenocarcinoma patients with enhanced FXR, FXR/RXR- $\beta$ or $-\gamma$ expression showed significantly longer survival times compared to those with low expression ( $\mathrm{p}=0.013, \mathrm{p}=0.021$ and $\mathrm{p}<0.001$, respectively). In multivariate analysis, FXR and FXR/RXR- $\gamma$ expression were identified as independent prognostic factors ( $\mathrm{p}=0.044$ and $\mathrm{p}=0.001$, respectively). Conclusion: The present study suggested that FXR and RXRs were implicated in pancreatic malignant disease progression, reinforcing their utility as clinical markers for patients' management and prognosis, as well as targets for potential therapeutic interventions.
\end{abstract}

Key words: FXR, RXR, pancreatic adenocarcinoma, immunohistochemistry, clinicopathological parameters, patients' survival

The Farnesoid X Receptor (FXR) is a member of the nuclear receptor (NR) superfamily of ligand-activated transcription factors, which play important roles in different aspects of human physiology and development [1]. FXR regulates the expression of various genes involved in bile acid, cholesterol, lipid and glucose metabolism, by binding to DNA either as a monomer or an heterodimer with Retinoid X Receptors (RXRs) to FXR response elements (FXREs) [2]. Two known FXR genes (official symbol, NR1H4) exist, the Fxr $\alpha$ and Fxr $\beta$. Fxr $\alpha$ gene in humans encodes four FXRa isoforms (FXRa1, FXRa2, FXRa3 and FXRa4) as a result of the use of different promoters and alternative RNA splicing $[2,3]$. The second FXR gene, $\operatorname{Fxr} \beta$, is a pseudogene in humans and its role remains uncertain [2, 3]. Most FXR target genes are regulated independently by all FXRa isoforms, while other target genes are more isoform-specific and response mainly to the FXR 22 and FXR $a 4$ isoforms [2, $3]$. On the other hand, three RXR genes exist, coding for RXR- $\alpha,-\beta$, and $-\gamma$, and each of them can produce different RXR isoforms through the use of alternative promoters or splice sites [4]. RXRs are common heterodimerization partners for several NRs beyond FXR, including thyroid receptors (TRs), vitamin $\mathrm{D}$ receptor (VDR), peroxisome proliferator-activated receptors (PPARs), liver X receptors (LXRs) and pregnane X receptors (PXR) [5]. However, it remains still unclear whether their role is restricted to act as 
co-partners for the other NRs or there is actually a separate RXR-mediated signalling pathway [6].

Pancreatic cancer is one of the most lethal malignant tumors presenting extremely poor prognosis, as survival longer than 5 years is actually rare $[7,8]$. Indeed, tumor resection is performed in $9-36 \%$ of patients and the 5-year survival rate of patients who have undergone resection is only $19-24 \%[7,8]$. Hence, there is a strong demand for novel specific markers to be explored in respect to pancreatic adenocarcinoma patients' management and prognosis. Moreover, chemotherapy, such as treatment with 5-fluorouracil or gemcitabine, is not potentially capable of contributing to significant survival benefit [9]. Thus, the establishment of alternative therapeutic approaches for the treatment of pancreatic cancer remains a great challenge.

In the last decade, FXR has been implicated in the pathogenesis of cholestatic, non-alcoholic fatty liver and inflammatory bowel disease [10-12]. FXR has also been involved in the development of atherosclerosis, intestinal bacterial growth and liver regeneration [13, 14]. Notably, recent accumulative evidence has further suggested that FXR may exert a potential protective role against tumorigenesis by promoting apoptosis and inhibiting cell proliferation [15]. However, apart from the gradually increasing research conducted on cultured cell lines and animal models, there is no comprehensive clinical data so far concerning the involvement of FXR in human malignant transformation [15]. In fact, certain small pilot cohort studies conducted on esophageal, breast, hepatocellular, pancreatic and colon carcinoma, which mostly did not concern potential associations of FXR expression with clinicopathological parameters and patients' prognosis, have currently been performed [1624]. In view of the above considerations, the present study aimed to assess immunohistochemically the expression of FXR and RXR- $\alpha,-\beta$ and $-\gamma$ in tumoral specimens obtained from pancreatic adenocarcinoma patients. We also aimed to evaluate the association of FXR expression, as well as the concomitant expression of FXR and RXR- $\alpha,-\beta$ and $-\gamma$ with clinicopathological characteristics, tumor proliferative capacity and patients' survival.

\section{Patients and methods}

Clinical material. Fifty-five pancreatic ductal adenocarcinoma specimens obtained from equal number of patients who underwent surgical resection due to pancreatic cancer were included in this study. The study was approved by the institutional ethical committee. None of the patients received any kind of anti-cancer treatment prior to surgery. Thirty five of the patients were men (63.6\%) and 20 women (36.4\%), with a mean age of $67.1 \pm 8.3$ years (range $33-84$ years). The cases were classified based on the World Health Organization criteria for histological grading as: well in 7 (12.7\%); moderately in 41 (74.5\%); poorly differentiated in $7(12.7 \%)$ [25]. Tumor staging was assessed using the 5th edition of the Tumor, Node, Metastasis (TNM) and the American Joint
Committee on Cancer (AJCC) Grouping system [26, 27]. In fact, tumors were classified as: T1 in 3 (5.5\%), T2 in $5(9.1 \%)$, T3 in $39(70.9 \%)$ and T4 in $8(14.5 \%)$ cases. Twenty-nine $(52.7 \%)$ were lymph node negative (N0), and $26(47.3 \%)$ were regional lymph node positive (N1). Organ metastasis was noted in 3 out of $55(5.5 \%)$ patients examined. According to the AJCC classification, 7 (12.7\%) cases were characterized as stage I, $37(67.3 \%)$ as stage II, $8(14.5 \%)$ as stage III and 3 $(5.5 \%)$ as stage IV. The patients were followed up until death for a time interval of 4 up to 21 months with a mean survival time of $8.71 \pm 3.54$ months. Overall survival was defined as the time interval between the date of surgery and the date of death due to pancreatic adenocarcinoma. At the time of the last follow-up, all patients died from the disease.

Immunohistochemistry. Immunostainings for FXR, RXR- $\alpha,-\beta$ and $-\gamma$ were performed on formalin-fixed, paraffinembedded tissue sections using commercially available rabbit polyclonal anti-FXR (H-130, sc-13063), anti-RXR- $\alpha$ (D-20, sc-553), anti-RXR- $\beta$ (C-20, sc-831) and anti-RXR- $\gamma$ (Y-20, sc-555) primary IgG antibodies (Santa Cruz Biochemicals, Santa Cruz, CA, USA). Briefly, $4 \mu \mathrm{m}$ thick tissue sections were dewaxed in xylene and were brought to water through graded alcohols. Antigen retrieval (citrate buffer at $\mathrm{pH} 6.1$ and microwave heating) was then performed. To remove the endogenous peroxidase activity, sections were then treated with freshly prepared $0.3 \%$ hydrogen peroxide in methanol in the dark, for 30 minutes ( $\mathrm{min}$ ), at room temperature. Nonspecific antibody binding was then blocked using Snipper, a specific blocking reagent for rabbit primary antibodies (Sniper, Biocare Medical, Walnut, Creek, CA, USA) for 5 min. The sections were then incubated for 1 hour $(\mathrm{h})$, at room temperature, with primary antibodies, diluted 1:200 in phosphate buffered saline (PBS). After washing three times with PBS, sections were incubated at room temperature with biotinylated linking reagent (Biocare Medical) for 10 min, followed by incubation with peroxidase-conjugated streptavidin label (Biocare Medical) for $10 \mathrm{~min}$. The resultant immune peroxidase activity was developed in $0.5 \%$ 3,3'-diaminobenzidine hydrochloride (DAB; Sigma, Saint Louis, MO, USA) in PBS containing $0.03 \%$ hydrogen peroxide for 3 min. Sections were counterstained with Harris' hematoxylin and mounted in Entellan (Merck, Darmstadt, Germany). Appropriate negative controls were performed by omitting the primary antibody and/or substituting it with an irrelevant anti-serum. As positive control, colon cancer tissue sections with known increased FXR expression [Theocharis et al., unpublished data] and carotid atherosclerotic plaques with known increased RXR- $\alpha,-\beta$ and $-\gamma$ expression [28] were used. The tumor cells' proliferative capacity was assessed immunohistochemically, using a mouse anti-human Ki-67 antigen; $\operatorname{IgG}_{1 \mathrm{k}}$ antibody (clone MIB-1, Dakopatts, Glostrup, Denmark) as previously described $[29,30]$.

Evaluation of immunohistochemistry. Immunohistochemical evaluation was performed by counting at least 1000 tumor cells in each case by two independent observers (S.T. 


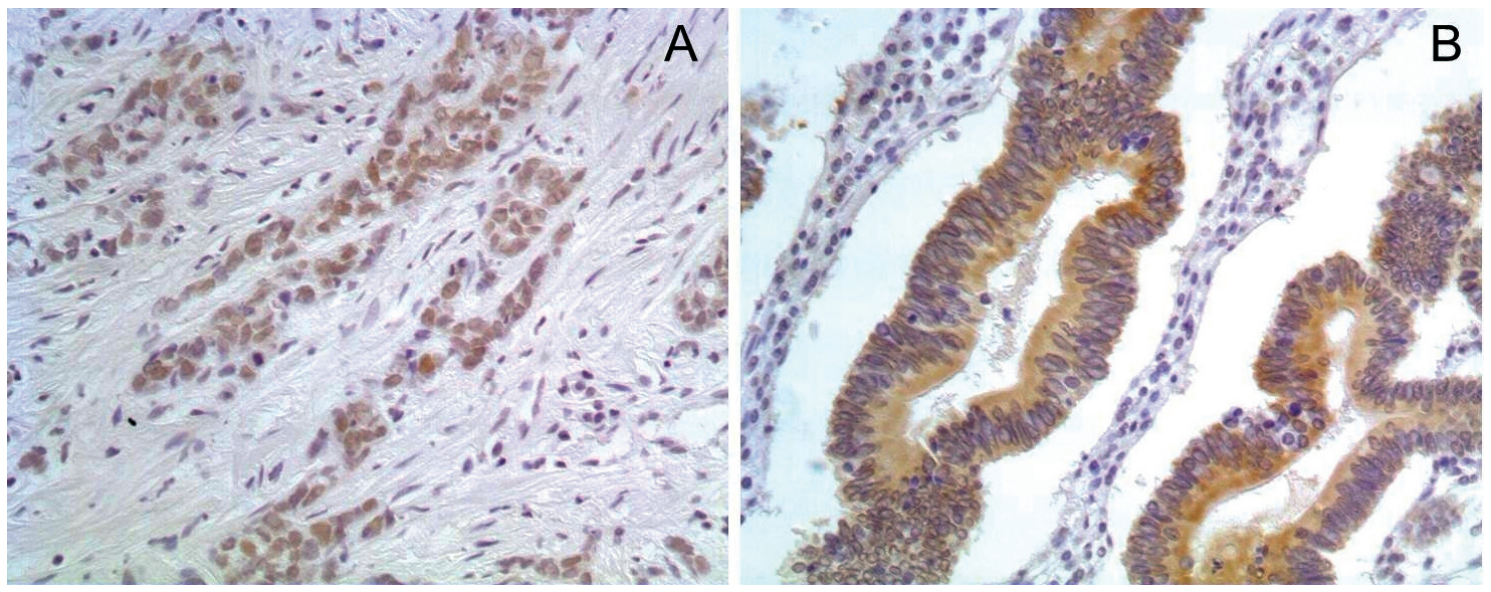

Figure 1. Representative immunostaining for FXR expression in pancreatic adenocarcinoma tumor cells presenting A. Nuclear and B. Both cytoplasmic and nuclear pattern of staining. Streptavidin-biotin-peroxidase, DAB chromogen, Harris hematoxylin counterstain (original magnification X200).

and P.A.) blinded to the clinical data, with complete observer agreement. Specimens were considered "positive" for FXR, RXR- $\alpha,-\beta$ and $-\gamma$ when more than $5 \%$ of tumor cells within

Table 1. Associations of FXR expression with clinicopathological variables in 55 pancreatic adenocarcinoma patients

\begin{tabular}{|c|c|c|c|}
\hline \multirow{2}{*}{$\begin{array}{l}\text { Clinicopathological } \\
\text { variables }\end{array}$} & \multicolumn{3}{|c|}{ FXR expression } \\
\hline & Low (\%) & High (\%) & $p$-value \\
\hline Patients $(\mathrm{N}=55)$ & $28(50.9)$ & $27(49.1)$ & \\
\hline Age $($ mean $\pm \mathrm{SD})$ & & & 0.346 \\
\hline$<67$ & $16(29.1)$ & $12(21.8)$ & \\
\hline$\geq 67$ & $12(27.3)$ & $15(21.8)$ & \\
\hline Gender & & & 0.508 \\
\hline Male & $19(34.5)$ & $16(29.1)$ & \\
\hline Female & $9(16.4)$ & $11(20.0)$ & \\
\hline Histological grade & & & 0.364 \\
\hline Well & $3(5.5)$ & $4(7.3)$ & \\
\hline Moderately & $23(41.8)$ & $18(32.7)$ & \\
\hline Poorly & $2(3.6)$ & $5(9.1)$ & \\
\hline $\mathrm{pT}$ & & & 0.113 \\
\hline $\mathrm{T} 1+\mathrm{T} 2$ & $2(3.6)$ & $6(10.9)$ & \\
\hline $\mathrm{T} 3+\mathrm{T} 4$ & $26(47.3)$ & $21(38.2)$ & \\
\hline $\mathrm{pN}$ & & & 0.135 \\
\hline No & $12(21.8)$ & $17(30.9)$ & \\
\hline N1 & $16(29.1)$ & $10(18.2)$ & \\
\hline pM & & & 0.574 \\
\hline M0 & $26(47.3)$ & $26(47.3)$ & \\
\hline M1 & $2(3.6)$ & $1(1.8)$ & \\
\hline pStage & & & 0.054 \\
\hline I & $1(1.8)$ & $6(10.9)$ & \\
\hline II & $19(34.5)$ & $18(32.7)$ & \\
\hline $\mathrm{III}+\mathrm{IV}$ & $8(14.5)$ & $3(5.5)$ & \\
\hline Ki-67 protein statement & & & 0.276 \\
\hline Low & $12(22.2)$ & $16(29.6)$ & \\
\hline High & $15(27.8)$ & $11(20.4)$ & \\
\hline
\end{tabular}

the section were positively stained. FXR, RXR- $\alpha,-\beta$ and $-\gamma$ immunoreactivity was scored according to the percentage of positive tumor cells as 0 : negative staining- $0-4 \%$ of cells positive; $1: 5-24 \%$ of cells positive; $2: 25-49 \%$ of cells positive; 3: $50-100 \%$ of cells positive, and its intensity as 0 : negative staining, 1 : mild staining; 2 : intermediate staining; 3 : intense staining. Finally, the expression of FXR, RXR- $\alpha,-\beta$ and $-\gamma$ was classified as low; if the total score was 0 or 2 and high; if the total score was $\geq 3$ [29-31]. In this way, we ensure that each group has a sufficient and more homogeneous number of cases in order to be comparable with the other groups [29-31].

Statistical analysis. Chi-square test was used to assess the associations of FXR, RXR- $\alpha,-\beta$ and $-\gamma$ protein expression with clinicopathological variables. Survival curves were constructed using the Kaplan-Meier method and the differences between the curves were compared by the log rank test. A Cox proportional-hazard regression model was developed to evaluate the association between the potential prognostic marker and overall survival, at multivariate level. A p-value less than 0.05 was considered the limit of statistical significance. SPSS for Windows Software was used for all analyses (SPSS Inc., 2003, Chicago, USA).

\section{Results}

Clinical significance of FXR expression in pancreatic adenocarcinoma. Thirty-three (60.0\%) out of 55 pancreatic adenocarcinoma cases were found FXR positive, presenting nuclear and/or cytoplasmic pattern of staining. Representative immunostainings for FXR are depicted in Figure 1. High FXR expression was noted in 27 (49.1\%) out of 55 pancreatic adenocarcinoma cases. Non-neoplastic sites of pancreatic tissues were found negative for FXR (data not shown).

In crosstabulation, high FXR expression was borderline associated with earlier histopathological stage (Table $1, \mathrm{p}=0.054$ ). 

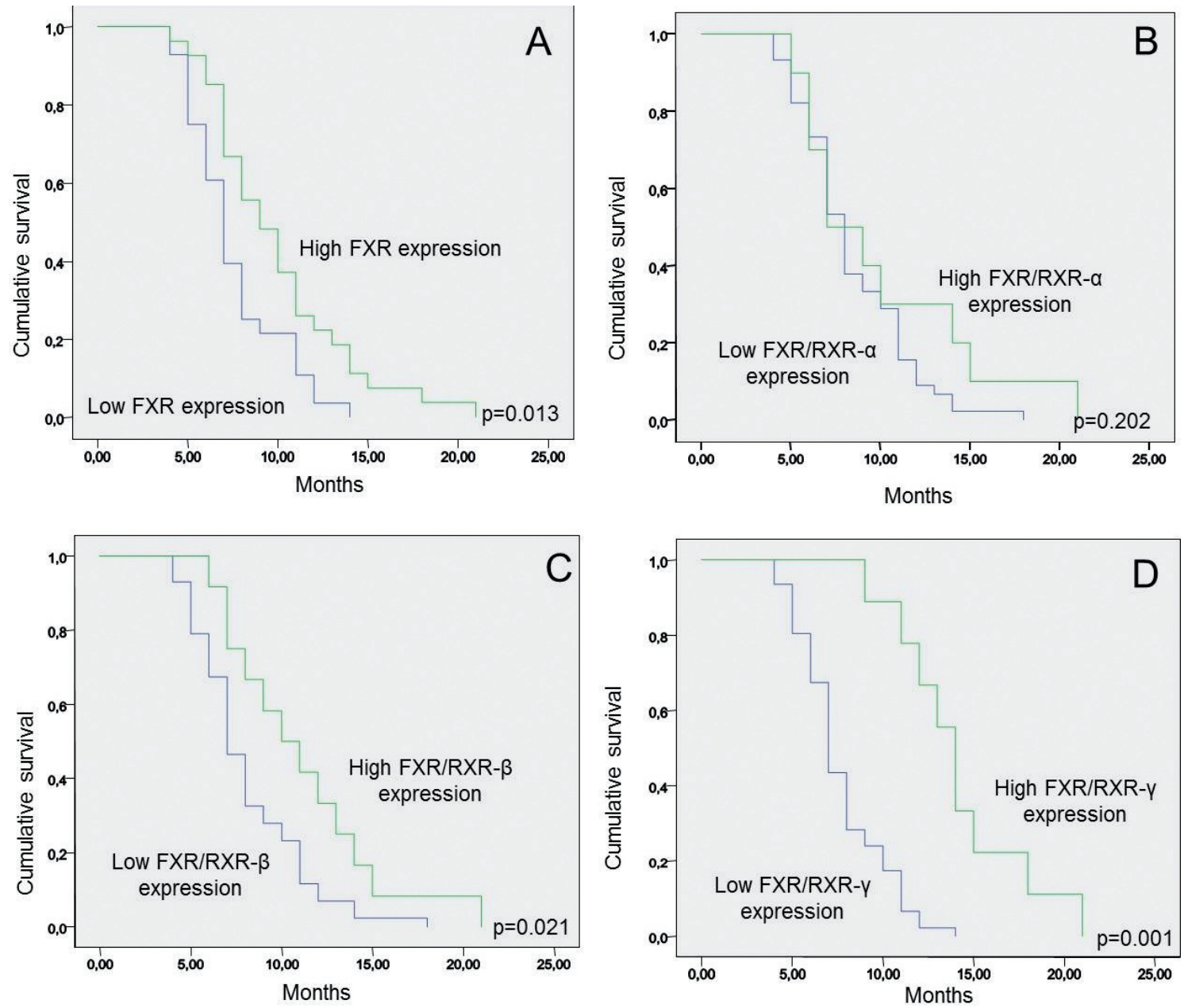

Figure 2. Kaplan-Meier survival analysis stratified according to A. FXR, B. FXR/RXR- $\alpha$, C. FXR/RXR- $\beta$ and D. FXR/RXR- $\gamma$ expression in pancreatic adenocarcinoma patients.

High FXR expression was more frequently observed in pancreatic adenocarcinoma patients presenting smaller tumor size and absence of lymph node metastases, at a non significant level though (Table $1, \mathrm{p}=0.113$ and $\mathrm{p}=0.135$, respectively). Younger and female pancreatic adenocarcinoma patients also showed a slightly but not significantly increased frequency of high FXR expression compared to older and male ones (Table $1, \mathrm{p}=0.346$ and $\mathrm{p}=0.508$, respectively). Kaplan-Meier survival curves indicated that pancreatic adenocarcinoma patients presenting high FXR expression had significantly longer survival times compared to those with low expression (Figure 2A, logrank test, $\mathrm{p}=0.013$ ). In multivariate analysis, FXR expression and histopathological stage were identified as independent prognostic factor of patients' survival (Cox-regression analysis, $\mathrm{p}=0.044$ and $\mathrm{p}<0.001$, respectively).

Clinical significance of concomitant FXR/RXR- $\alpha$, $-\beta$ and $-\gamma$ expression in pancreatic adenocarcinoma. Of the 55 pancreatic adenocarcinoma cases, high RXR- $\alpha,-\beta$ or $-\gamma$ expression was noted in 19 (34.5\%), 22 (40.0\%) and 21 (38.2\%) cases, respectively. Non-neoplastic sites of pancreatic tissues were found negative for RXR- $\alpha,-\beta$ and $-\gamma$ (data not shown). Concomitant high FXR/RXR- $\alpha,-\beta$ or $-\gamma$ expression was noted in $10(18.2 \%), 12(21.8 \%)$ and $9(16.4 \%)$ cases, respectively. FXR expression was not associated with RXR- $\alpha,-\beta$ and $-\gamma$ expression ( $p=0.853, p=0.509$ and $p=0.864$, respectively).

In crosstabulation, concomitant high FXR/RXR- $\alpha$ expression was significantly more frequently observed in pancreatic adenocarcinoma patients presenting decreased tumor histological grade of differentiation (Table 2, $\mathrm{p}=0.017$ ), and marginally in female compared to male patients (Table 2, $\mathrm{p}=0.086$ ). Concomitant high FXR/RXR- $\beta$ expression was significantly associated with earlier histopathological stage and smaller tumor size, and marginally with the absence of lymph node metastases (Table $3, \mathrm{p}=0.017, \mathrm{p}=0.037$ and $\mathrm{p}=0.081$, respectively). Concomitant high FXR/RXR- $\gamma$ expression was significantly associated with earlier histopathological stage, smaller tumor size and the absence of lymph node metastases (Table $4, \mathrm{p}=0.004, \mathrm{p}=0.005$ and $\mathrm{p}=0.018$, respectively). 
Table 2. Associations of concomitant FXR/RXR- $\alpha$ expression with clinicopathological variables in 55 pancreatic adenocarcinoma patients

\begin{tabular}{|c|c|c|c|}
\hline \multirow{2}{*}{$\begin{array}{l}\text { Clinicopathological } \\
\text { variables }\end{array}$} & \multicolumn{3}{|c|}{ FXR/RXR- $\alpha$ expression } \\
\hline & Low (\%) & High (\%) & $p$-value \\
\hline Patients $(\mathrm{N}=55)$ & $45(81.8)$ & $10(18.2)$ & \\
\hline Age (mean $\pm S D)$ & & & 0.525 \\
\hline$<67$ & $22(40.0)$ & $6(10.9)$ & \\
\hline$\geq 67$ & $23(41.8)$ & $4(7.3)$ & \\
\hline Gender & & & 0.086 \\
\hline Male & $31(56.4)$ & $4(7.3)$ & \\
\hline Female & $14(25.5)$ & $6(10.9)$ & \\
\hline Histological grade & & & 0.017 \\
\hline Well & $3(5.5)$ & $4(7.3)$ & \\
\hline Moderately & $36(65.5)$ & $5(9.1)$ & \\
\hline Poorly & $6(10.9)$ & $1(1.8)$ & \\
\hline p'T & & & 0.125 \\
\hline $\mathrm{T} 1+\mathrm{T} 2$ & $5(9.1)$ & $3(5.5)$ & \\
\hline $\mathrm{T} 3+\mathrm{T} 4$ & $40(72.7)$ & $7(12.7)$ & \\
\hline $\mathrm{pN}$ & & & 0.226 \\
\hline No & $22(40.0)$ & $7(12.7)$ & \\
\hline N1 & $23(41.8)$ & $3(5.5)$ & \\
\hline pM & & & 0.401 \\
\hline M0 & $42(76.4)$ & $10(18.2)$ & \\
\hline M1 & $3(5.5)$ & $0(0)$ & \\
\hline pStage & & & 0.168 \\
\hline $\mathrm{I}$ & $4(7.3)$ & $3(5.5)$ & \\
\hline II & $31(56.4)$ & $6(10.9)$ & \\
\hline $\mathrm{III}+\mathrm{IV}$ & $10(18.2)$ & $1(1.8)$ & \\
\hline Ki-67 protein statement & & & 0.525 \\
\hline Low & $22(40.0)$ & $6(10.9)$ & \\
\hline High & $23(41.8)$ & $4(7.3)$ & \\
\hline
\end{tabular}

Kaplan-Meier survival curves indicated that pancreatic adenocarcinoma patients presenting concomitant high FXR/ RXR- $\alpha$ expression showed longer survival times compared to those with low expression, at a non significant level though (Figure 2B, log-rank test, $\mathrm{p}=0.202$ ). Pancreatic adenocarcinoma patients presenting concomitant high FXR/RXR- $\beta$ expression showed significantly longer survival times compared to those with low expression (Figure 2C, log-rank test, $\mathrm{p}=0.021$ ). Pancreatic adenocarcinoma patients presenting concomitant high FXR/RXR- $\gamma$ expression showed significantly longer survival times compared to those with low expression (Figure 2D, log-rank test, $\mathrm{p}=0.001$ ). In multivariate analysis, histopathological stage and concomitant FXR/RXR- $\gamma$ but not FXR/RXR- $\beta$ expression were identified as independent prognostic factors for patients' survival (Cox-regression analysis, $\mathrm{p}=0.001, \mathrm{p}=0.001$ and $\mathrm{p}=0.133$, respectively).

\section{Discussion}

Undergoing research is currently focused on the role of FXR in crucial biochemical and cellular processes implicated in several pathological disease states, such as cholestatic,
Table 3. Associations of concomitant FXR/RXR- $\beta$ expression with clinicopathological variables in $\mathbf{5 5}$ pancreatic adenocarcinoma patients.

\begin{tabular}{|c|c|c|c|}
\hline \multirow{2}{*}{$\begin{array}{l}\text { Clinicopathological } \\
\text { variables }\end{array}$} & \multicolumn{3}{|c|}{ FXR/RXR- $\beta$ expression } \\
\hline & Low (\%) & High (\%) & $p$-value \\
\hline Patients $(\mathrm{N}=55)$ & $43(78.2)$ & $12(21.8)$ & \\
\hline Age $($ mean $\pm S D)$ & & & 0.561 \\
\hline$<67$ & $21(38.2)$ & $7(12.7)$ & \\
\hline$\geq 67$ & $22(40.0)$ & $5(9.1)$ & \\
\hline Gender & & & 0.267 \\
\hline Male & $29(52.7)$ & $6(10.9)$ & \\
\hline Female & $14(25.5)$ & $6(10.9)$ & \\
\hline Histological grade & & & 0.778 \\
\hline Well & $5(9.1)$ & $2(3.6)$ & \\
\hline Moderately & $33(60.0)$ & $8(14.5)$ & \\
\hline Poorly & $5(9.1)$ & $2(3.6)$ & \\
\hline $\mathrm{pT}$ & & & 0.037 \\
\hline $\mathrm{T} 1+\mathrm{T} 2$ & $4(7.3)$ & $4(7.3)$ & \\
\hline $\mathrm{T} 3+\mathrm{T} 4$ & $39(70.9)$ & $8(14.5)$ & \\
\hline pN & & & 0.081 \\
\hline No & $20(36.4)$ & $9(16.4)$ & \\
\hline N1 & $23(41.8)$ & $3(5.5)$ & \\
\hline pM & & & 0.347 \\
\hline M0 & $40(72.7)$ & $12(21.8)$ & \\
\hline M1 & $3(5.5)$ & $0(0)$ & \\
\hline pStage & & & 0.017 \\
\hline I & $3(5.5)$ & $4(7.3)$ & \\
\hline II & $29(52.7)$ & $8(14.5)$ & \\
\hline $\mathrm{III}+\mathrm{IV}$ & $11(20.0)$ & $0(0)$ & \\
\hline Ki-67 protein statement & & & 0.267 \\
\hline Low & $20(36.4)$ & $8(14.5)$ & \\
\hline High & $23(41.8)$ & $4(7.3)$ & \\
\hline
\end{tabular}

non-alcoholic fatty liver and inflammatory bowel disease, atherosclerosis, intestinal bacterial growth and liver regeneration as recently reviewed by our group [15]. A gradually growing body of in vitro and animal studies has further extended the role of FXR in oncogenic transformation [15]. However, to the best of our knowledge, no comprehensive data concerning the involvement of FXR and its co-partners RXRs in human malignancy still exist in the literature. Moreover, the assessment of the clinical significance of FXR expression in human malignancies remains scarce, being restricted to a small number of cohort studies conducted on esophageal, breast, hepatocellular, pancreatic and colon carcinoma that mostly did not concern associations with clinicopathological parameters and patients' prognosis [16-24].

In this aspect, the present study assessed for the first time the concomitant expression levels of FXR and RXRs in tumoral samples of pancreatic adenocarcinoma patients, investigating their association with crucial clinicopathological characteristics and patients' survival. According to our study, enhanced FXR expression was associated with higher differentiated histopathological stage and favourable patients' prognosis, at both univariate and multivariate levels. Moreover, concomitant 
enhanced FXR/RXR- $\alpha$ expression was associated with tumor histological grade, while concomitant enhanced FXR/RXR- $\beta$ and $-\gamma$ expression with higher differentiated histopathological stage, smaller tumor size and favourable patients' prognosis. Moreover, concomitant enhanced FXR/RXR- $\gamma$ expression was further associated with the absence of lymph node metastases. These findings supported evidence for a potential crucial role of FXR in pancreatic malignant disease progression that affect patients' survival. Moreover, taking into consideration that FXR heterodimerization with RXRs is an essential step for its transcriptional activity, the strong associations of concomitant FXR/RXRs expression with crucial clinicopathological parameters and patients' survival supported evidence for potential functional partnership between FXR and RXRs in pancreatic malignant transformation.

Concerning the existing clinical evidence so far, FXR expression was inversely correlated with neoplastic transformation/progression and inflammation severity in ulcerative colitis [23]. Moreover, primary sclerosing cholangitis - ulcerative colitis patients presented diminished FXR expression in the proximal colon compared to ulcerative colitis patients [23]. In human hepatocellular carcinoma, FXR expression was down-regulated, being also positively correlated with multiple malignant clinicopathological characteristics [21]. FXR overexpression was associated with poor histopathological grade, larger tumor size and presence of lymph node metastasis in 59 esophageal adenocarcinoma patients [24]. FXR was also detected in non dysplastic tissue but its expression was lost during progression to dysplasia and adenocarcinoma in Barrett's esophagus patients [20]. In addition, FXR was detected in normal and tumoral breast tissue, presenting enhanced expression levels in ductal epithelial cells of normal breast and infiltrating ductal carcinoma cells [17]. An immunohistochemical analysis on 204 breast carcinoma patients further established significant correlations between FXR expression and estrogen receptor (ER), Ki-67, cyclin D and p27 expression [18]. FXR mRNA levels were reduced in adenomas compared to normal colorectal mucosa, while an even more pronounced decrease in colon carcinomas was recorded [16]. In another study, FXR expression was reduced in colon carcinoma compared to peritumoral nonneoplastic mucosa [22]. Loss of FXR expression was correlated with tumor grade in the right colon. Moreover, FXR expression in tumor and normal colon tissue showed an inverse correlation with histopathological stage, while FXR expression in tumor was inversely correlated with clinical outcome [22]. In a recent cohort study conducted on 34 pancreatic cancer patients, FXR overexpression was associated with the presence of lymph node metastasis and poor patients' outcome [19]. These findings are not in line with our results, which may be ascribed to the smaller number of pancreatic adenocarcinoma cases examined in the above study and the different primary antibody used to detect FXR immunoreactivity. Moreover, the above study evaluated FXR immunoreactivity according to the proportion of FXR positive tumor cells. In contrast, in our study an immunohistochemical
Table 4. Associations of concomitant FXR/RXR- $\gamma$ expression with clinicopathological variables in 55 pancreatic adenocarcinoma patients.

\begin{tabular}{|c|c|c|c|}
\hline \multirow{2}{*}{$\begin{array}{l}\text { Clinicopathological } \\
\text { variables }\end{array}$} & \multicolumn{3}{|c|}{ FXR/RXR- $\gamma$ expression } \\
\hline & Low (\%) & High (\%) & $p$-value \\
\hline Patients $(\mathrm{N}=55)$ & $46(83.6)$ & $9(16.4)$ & \\
\hline Age $($ mean $\pm S D)$ & & & 0.671 \\
\hline$<67$ & $24(43.6)$ & $4(7.3)$ & \\
\hline$\geq 67$ & $22(40.0)$ & $5(9.1)$ & \\
\hline Gender & & & 0.582 \\
\hline Male & $30(54.5)$ & $5(9.1)$ & \\
\hline Female & $16(29.1)$ & $4(7.3)$ & \\
\hline Histological grade & & & 0.646 \\
\hline Well & $5(9.1)$ & $2(3.6)$ & \\
\hline Moderately & $35(63.6)$ & $6(10.9)$ & \\
\hline Poorly & $6(10.9)$ & $1(1.8)$ & \\
\hline $\mathrm{pT}$ & & & 0.005 \\
\hline $\mathrm{T} 1+\mathrm{T} 2$ & $4(7.3)$ & $4(7.3)$ & \\
\hline $\mathrm{T} 3+\mathrm{T} 4$ & $42(76.4)$ & $5(9.1)$ & \\
\hline pN & & & 0.018 \\
\hline No & $21(38.2)$ & $8(14.5)$ & \\
\hline N1 & $25(45.5)$ & $1(1.8)$ & \\
\hline pM & & & 0.431 \\
\hline M0 & $43(78.2)$ & $9(16.4)$ & \\
\hline M1 & $3(5.5)$ & $0(0)$ & \\
\hline pStage & & & 0.004 \\
\hline I & $3(5.5)$ & $4(7.3)$ & \\
\hline II & $32(58.2)$ & $5(9.1)$ & \\
\hline $\mathrm{III}+\mathrm{IV}$ & $11(20.0)$ & $0(0)$ & \\
\hline Ki-67 protein statement & & & 0.760 \\
\hline Low & $23(41.8)$ & $5(9.1)$ & \\
\hline High & $23(41.8)$ & $4(7.3)$ & \\
\hline
\end{tabular}

score based on both the proportion of FXR positive tumor cells and the intensity of FXR immunostaining was applied.

Several in vitro and animal studies have documented that FXR may be considered as a potential molecular target in pancreatic neoplasia. In fact, down-regulation of FXR expression in human pancreatic MIA-PaCa2 and PANC-1 cancer cells inhibited cell proliferation and migration [19]. Notably, FXR down-regulation by siRNA transfection decreased NF- $\kappa B$ DNA-binding activity and vascular endothelial growth factor (VEGF) levels, while treatment with the FXR antagonist, guggulsterone, inhibited cell proliferation, migration and invasion in a dose-dependent manner [19]. Treatment with the FXR agonist, GW4064, increased cell migration and invasion in both MIA-PaCa2 and PANC-1 cancer cells [19]. In addition, the naturally derived isoprenoids perillyl alcohol, farnesol and geraniol exhibited an additive antiproliferative effect against human pancreatic MIA PaCa-2 and BxPC-3 cancer cells, inducing G0/G1 cell cycle arrest [32]. Although farnesol is a weak FXR activator and such activation could not be considered as a general mechanism in farnesol-induced apoptosis, the possibility of its interaction with FXR cannot be excluded [32]. In another study, farnesol, geraniol or perillyl alcohol 
treatment resulted in a 3-10 fold increase in apoptosis and Bak expression of BxPC3 pancreatic cancer cells [33]. It was also showed that pancreatic carcinoma incidence was decreased in animal models fed with perillyl alcohol and farnesol diets, while increased apoptotic rates and diminished expression of the antiapoptotic protein BCL-XL [33].

Substantial evidence has further supported that RXRs can function either as homodimers or heterodimers with NRs, including FXR, being involved in manifesting antiproliferative effects in cancer cells [34]. Clinical evidence has suggested that RXRs may be implicated in tumor development progression, being associated with crucial clinicopathological parameters and/or patients' prognosis in certain human malignancies, including esophageal, breast, lung, pancreatic, renal cell, prostate and ovarian carcinoma, melanoma and osteosarcoma $[29,35-42]$. It has also been documented that retinoids, such as all-trans-retinoic acid (atRA; tretinoin), 9-cis-RA and 13-cis-retinoic acid (13-cis-RA; isotretinoin) negatively regulated cell proliferation in pancreatic cancer cell lines [43-45]. Accordingly, several RXR-agonists exhibited increased antitumor efficacy when combined with antiestrogens in breast cancer models and with standard chemotherapeutic agents in a variety of cancer types [46, 47]. LGD1069, a RXR agonist also inhibited tumor-induced angiogenesis via suppression of VEGF in non-small cell lung carcinoma [48].

In the last few years, a significant amount of research has been conducted and, although none has reached clinical use, many synthetic FXR ligands have extensively been studied $[49,50]$. In this aspect, FXR has emerged as a highly promising target in preclinical development $[49,50]$. FXR deficiency resulted in increased intestinal tumorigenesis and colon cell proliferation, which was accompanied by expression up-regulation of genes involved in cell cycle progression and inflammation [51, 52]. Interestingly, in human colon cancer cells, Src-mediated cross-talk between FXR and EGFR modulated ERK phosphorylation, thereby regulating intestinal cell proliferation and tumorigenesis [53]. Moreover, FXR activation was considered to exert an important role in protecting against carcinogenic effects of bile acids in gastrointestinal tumors [54]. Additionally, FXR deficiency in mice led to the development of spontaneous hepatocarcinomas, whereas FXR ligand activation inhibited the expression of hepatic inflammatory mediators in response to NF- $\mathrm{kB}$ activation, supporting the role of FXR as a central hepatoprotector and suppressor of hepatocarcinogenesis [55]. Treatment with the FXR antagonist guggulsterone enhanced apoptosis in a human Barrett's esophagus cell line [56]. FXR inactivation by FXR shRNA or guggulsterone also suppressed esophageal cancer cell growth and induced apoptosis, in vitro, as well as reduced tumor formation and growth in nude mouse xenografts [24]. FXR seemed to play a protective role in breast cancer development, being considered as a promising target for the development of novel anticancer agents [57]. Overall, from a therapeutic point of view, future strategies aimed at activating or inhibiting FXR expression may be useful in the treatment of certain types of human malignancy.

\section{Conclusion}

The present study showed for the first time that elevated FXR and concomitant elevated FXR/RXRs expression were associated with clinicopathological parameters, such as grade of differentiation, higher histopathological stage, smaller tumor size and absence of lymph node metastases, which are considered crucial for patients' management and prognosis. Even of more clinical significance are the data, supporting the association of FXR and concomitant FXR/RXRs expression with patients' survival. These findings supported evidence of a potential important role of FXR and RXRs in the biological mechanisms governing pancreatic malignant disease progression. The potential implication of FXR and its partnership with RXRs in the pancreatic adenocarcinoma, along with only few observations in this field, point out the necessity for further studies in order to clarify the potential role of these molecules and their possible use in the established therapeutic regimens of this type of malignancy.

\section{References}

[1] CHAWLA A, REPA JJ, EVANS RM, MANGELSDORF DJ. Nuclear receptors and lipid physiology: opening the X-files. Science 2001; 294: 1866-1870. http://dx.doi.org/10.1126/ science.294.5548.1866

[2] WANG YD, CHEN WD, MOORE DD, HUANG W. FXR: a metabolic regulator and cell protector. Cell Res 2008; 18: 1087-1095. http://dx.doi.org/10.1038/cr.2008.289

[3] PELLICCIARI R, COSTANTINO G, FIORUCCI S. Farnesoid $\mathrm{X}$ receptor: from structure to potential clinical applications. J Med Chem 2005; 48: 5383-5403. http://dx.doi.org/10.1021/ jm0582221

[4] MANGELSDORF DJ, BORGMEYER U, HEYMAN RA, ZHOU JY, ONG ES et al. Characterization of three RXR genes that mediate the action of 9-cis retinoic acid. Genes Dev 1992; 6: 329-344. http://dx.doi.org/10.1101/gad.6.3.329

[5] GERMAIN P, CHAMBON P, EICHELE G, EVANS RM, LAZAR MA et al. International Union of Pharmacology. LXIII Retinoid X Receptors. Pharmacol Rev 2006; 58: 760-772. http://dx.doi.org/10.1124/pr.58.4.7

[6] SZANTO A, NARKAR V, SHEN Q, URAY IP, DAVIES PJA, et al. Retinoid X receptors: X-ploring their (patho)physiological functions. Cell Death Differ 2004; 2: S126-143. http://dx.doi. org/10.1038/sj.cdd.4401533

[7] HIDALGO M. Pancreatic cancer. N Engl J Med 2010; 362: 1605-1617. http://dx.doi.org/10.1056/NEJMra0901557

[8] MA J, JEMAL A. The rise and fall of cancer mortality in the USA: why does pancreatic cancer not follow the trend? Future Oncol 2013; 9: 917-919. http://dx.doi.org/10.2217/ fon. 13.76

[9] PAULSON AS, TRAN CAO HS, TEMPERO MA, LOWY AM. Therapeutic advances in pancreatic cancer. Gastroen- 
terology 2013; 144: 1316-1326. http://dx.doi.org/10.1053/j. gastro.2013.01.078

[10] JONKER JW, LIDDLE C, DOWNES M. FXR and PXR: potential therapeutic targets in cholestasis. J Steroid Biochem Mol Biol 2012; 130: 147-158. http://dx.doi.org/10.1016/j. jsbmb.2011.06.012

[11] ADORINI L, PRUZANSKI M, SHAPIRO D. Farnesoid X receptor targeting to treat nonalcoholic steatohepatitis. Drug Discov Today 2012; 17: 988-997. http://dx.doi.org/10.1016/j. drudis.2012.05.012

[12] STOJANCEVIC M, STANKOV K, MIKOV M. The impact of farnesoid $\mathrm{X}$ receptor activation on intestinal permeability in inflammatory bowel disease. Can J Gastroenterol 2012; 26: 631-637.

[13] GADALETA RM, VAN MIL SW, OLDENBURG B, SIERSEMA PD, KLOMP LW, et al. Bile acids and their nuclear receptor FXR: Relevance for hepatobiliary and gastrointestinal disease. Biochim Biophys Acta 2010; 1801: 683-692. http://dx.doi.org/10.1016/j.bbalip.2010.04.006

[14] MENCARELLI A, FIORUCCI S. FXR an emerging therapeutic target for the treatment of atherosclerosis. J Cell Mol Med 2010; 14: 79-92. http://dx.doi.org/10.1111/j.1582-4934 $.2009 .00997 . x$

[15] KOUTSOUNAS I, GIAGINIS C, THEOCHARIS S. Farnesoid X Receptor (FXR) from normal to malignant state. Histol Histopathol 2012; 27: 835-853.

[16] DE GOTTARDI A, TOURI F, MAURER CA, PEREZ A, MAURHOFER $O$ et al. The bile acid nuclear receptor FXR and the bile acid binding protein IBABP are differently expressed in colon cancer. Dig Dis Sci 2004; 49: 982-989. http://dx.doi. org/10.1023/B:DDAS.0000034558.78747.98

[17] SWALES KE, KORBONITS M, CARPENTER R, WALSH DT, WARNER TD, et al. The farnesoid $\mathrm{X}$ receptor is expressed in breast cancer and regulates apoptosis and aromatase expression. Cancer Res 2006; 66: 10120-10126. http://dx.doi. org/10.1158/0008-5472.CAN-06-2399

[18] JOURNE F, DURBECQ V, CHABOTEAUX C, ROUAS G, LAURENT G et al. Association between farnesoid X receptor expression and cell proliferation in estrogen receptor-positive luminal-like breast cancer from postmenopausal patients. Breast Cancer Res Treat 2009; 115: 523-535. http://dx.doi. org/10.1007/s10549-008-0094-2

[19] LEE JY, LEE KT, LEE JK, LEE KH, JANG KT et al. Farnesoid $\mathrm{X}$ receptor, overexpressed in pancreatic cancer with lymph node metastasis promotes cell migration and invasion. $\mathrm{Br}$ J Cancer 2011; 104: 1027-1037. http://dx.doi.org/10.1038/ bjc.2011.37

[20] VAN DE WINKEL A, VAN ZOEST KP, VAN DEKKEN H, MOONS LM, KUIPERS EJ et al. Differential expression of the nuclear receptors farnesoid X receptor (FXR) and pregnane X receptor (PXR) for grading dysplasia in patients with Barrett's oesophagus. Histopathology 2011; 58: 246-253. http://dx.doi. org/10.1111/j.1365-2559.2011.03743.x

[21] SU H, MA C, LIU J, LI N, GAO M et al. Downregulation of nuclear receptor FXR is associated with multiple malignant clinicopathological characteristics in human hepatocellular carcinoma. Am J Physiol Gastrointest Liver
Physiol 2012; 303: G1245-1253. http://dx.doi.org/10.1152/ ajpgi.00439.2011

[22] LAX S, SCHAUER G, PREIN K, KAPITAN M, SILBERT D, et al. Expression of the nuclear bile acid receptor/farnesoid $\mathrm{X}$ receptor is reduced in human colon carcinoma compared to nonneoplastic mucosa independent from site and may be associated with adverse prognosis. Int J Cancer 2012; 130: 2232-2239. http://dx.doi.org/10.1002/ijc.26293

[23] TORRES J, BAO X, IUGA AC, CHEN A, HARPAZ N et al. Farnesoid $\mathrm{X}$ receptor expression is decreased in colonic mucosa of patients with primary sclerosing cholangitis and colitis-associated neoplasia. Inflamm Bowel Dis 2013; 19: 275-282. http://dx.doi.org/10.1097/MIB.0b013e318286ff2e

[24] GUAN B, LI H, YANG Z, HOQUE A, XU X. Inhibition of farnesoid $\mathrm{X}$ receptor controls esophageal cancer cell growth in vitro and in nude mouse xenografts. Cancer 2013; 119: 1321-1329. http://dx.doi.org/10.1002/cncr.27910

[25] KLOEPPEL G, SOLCIA E, LONGNECKER D, CAPELLA C, SOBIN LH. International histological classifications for tumors. In: World Health Organization, Histological Typing for Tumors of the Exocrine Pancreas. 2nd ed. Berlin: Spinger, 1996: 1-60. http://dx.doi.org/10.1007/978-3-642-61024-0

[26] SOBIN LH, WITTEKIND C. TNM Classification of Malignant Tumors. 5th ed. New York: Wiley-Liss, 1997; pp 170-173.

[27] GREENE FL, PAGE DL, FLEMING ID, FRITZ A, BALCH CM, et al. In: American Joint Committee on Cancer: AJCC Cancer Staging Manual. 6th ed, New York, NY, USA: Springer, 2002: 157-164.

[28] GIAGINIS C, KLONARIS C, KATSARGYRIS A, KOURAKLIS G, SPILIOPOULOU C, et al. Correlation of Peroxisome Proliferator-Activated Receptor-gamma (PPAR-gamma) and Retinoid X Receptor-alpha (RXR-alpha) expression with clinical risk factors in patients with advanced carotid atherosclerosis. Med Sci Monit 2011; 17: CR381-391. http://dx.doi. org/10.12659/MSM.881849

[29] GIAGINIS C, KATSAMANGOU E, TSOUROUFLIS G, ZIZI-SERBETZOGLOU D, KOURAKLIS G, et al. Peroxisome proliferator-activated receptor-gamma and retinoid $\mathrm{X}$ receptor-alpha expression in pancreatic ductal adenocarcinoma: association with clinicopathological parameters, tumor proliferative capacity, and patients's survival. Med Sci Monit 2009; 15: BR148-156.

[30] GIAGINIS C, TSOUROUFLIS G, ZIZI-SERBETZOGLOU A, KOURAKLIS G, CHATZOPOULOU E et al. Clinical significance of ephrin (eph)-A1, -A2, -a 4, -a5 and -a7 receptors in pancreatic ductal adenocarcinoma. Pathol Oncol Res 2010; 16: 267-276. http://dx.doi.org/10.1007/s12253-009-9221-6

[31] THEOCHARIS S, KLIJANIENKO J, GIAGINIS C, RODRIGUEZ J, JOUFFROY $\mathrm{T}$ et al. Metallothionein expression in mobile tongue squamous cell carcinoma: associations with clinicopathological parameters and patient survival. Histopathology 2011; 59:514-525. http://dx.doi.org/10.1111/ j.1365-2559.2011.03947.x

[32] WISEMAN DA, WERNER SR, CROWELL PL. Cell cycle arrest by the isoprenoids perillyl alcohol, geraniol, and farnesol is mediated by p21(Cip1) and p27(Kip1) in hu- 
man pancreatic adenocarcinoma cells. J Pharmacol Exp Ther 2007; 320: 1163-1170. http://dx.doi.org/10.1124/ jpet.106.111666

[33] BURKE YD, AYOUBI AS, WERNER SR, MCFARLAND BC, HEILMAN DK et al. Effects of the isoprenoids perillyl alcohol and farnesol on apoptosis biomarkers in pancreatic cancer chemoprevention. Anticancer Res 2002; 22: 3127-3134.

[34] SINGH RR, GURURAJ AE, VADLAMUDI RK, KUMAR R. 9-cis-retinoic acid up-regulates expression of transcriptional coregulator PELP1, a novel coactivator of the retinoid X receptor alpha pathway. J Biol Chem 2006; 281: 15394-15404. http://dx.doi.org/10.1074/jbc.M601593200

[35] FUJISHIMA F, SUZUKI T, NAKAMURA Y, TANIYAMA $\mathrm{Y}$, ONO $\mathrm{K}$ et al. Retinoid receptors in human esophageal squamous cell carcinoma: retinoid $\mathrm{X}$ receptor as a potent prognostic factor. Pathol Int 2011; 61: 401-408. http://dx.doi. org/10.1111/j.1440-1827.2011.02674.x

[36] CONDE I, LOBO MV, ZAMORA J, PEREZ J, GONZALEZ $\mathrm{FJ}$ et al. Human pregnane $\mathrm{X}$ receptor is expressed in breast carcinomas, potential heterodimers formation between $\mathrm{hPXR}$ and RXR-alpha. BMC Cancer $2008 ; 8: 174$. http://dx.doi. org/10.1186/1471-2407-8-174

[37] BRABENDER J, METZGER R, SALONGA D, DANENBERG KD, DANENBERG PV et al. Comprehensive expression analysis of retinoic acid receptors and retinoid $\mathrm{X}$ receptors in non-small cell lung cancer: implications for tumor development and prognosis. Carcinogenesis 2005; 26: 525-530. http:// dx.doi.org/10.1093/carcin/bgi006

[38] BUENTIG N, STOERKEL S, RICHTER E, DALLMANN I, REITZ M, ATZPODIEN J. Predictive impact of retinoid $\mathrm{X}$ receptor-alpha-expression in renal-cell carcinoma. Cancer Biother Radiopharm 2004; 19: 331-342. http://dx.doi. org/10.1089/1084978041425007

[39] OBARA W, KONDA R, AKASAKA S, NAKAMURA S, SUGAWARA A et al. Prognostic significance of vitamin $\mathrm{D}$ receptor and retinoid $\mathrm{X}$ receptor expression in renal cell carcinoma. J Urol 2007; 178: 1497-1503. http://dx.doi. org/10.1016/j.juro.2007.05.119

[40] KAISER PC, KÖRNER M, KAPPELER A, AEBI S. Retinoid receptors in ovarian cancer: expression and prognosis. Ann Oncol 2005; 16: 1477-1487. http://dx.doi.org/10.1093/annonc/mdi265

[41] CHAKRAVARTI N, LOTAN R, DIWAN AH, WARNEKE CL, JOHNSON MM et al. Decreased expression of retinoid receptors in melanoma: entailment in tumorigenesis and prognosis. Clin Cancer Res 2007; 13: 4817-4824. http://dx.doi. org/10.1158/1078-0432.CCR-06-3026

[42] GALLAGHER R, KEIGHLEY J, TANCABELIC J, GARIMELLA R, PINSON D et al. Clinicopathologic correlation of vitamin $\mathrm{D}$ receptor expression with retinoid $\mathrm{X}$ receptor and MIB-1 expression in primary and metastatic osteosarcoma. Ann Diagn Pathol 2012; 16: 323-329. http://dx.doi. org/10.1016/j.anndiagpath.2012.01.001

[43] ROSEWICZ S, STIER U, BREMBECK F, KAISER A, PAPADIMITRIOU CA et al. Retinoids: effects on growth, differentiation, and nuclear receptor expression in human pancreatic carcinoma cell lines. Gastroenterology 1995; 109:1646-1660. http://dx.doi.org/10.1016/0016-5085(95)90655-X

[44] BALASUBRAMANIAN S, CHANDRARATNA RAS, ECKERT R. Suppression of human pancreatic cancer cell proliferation by AGN194204, an RXR-selective retinoid. Carcinogenesis 2004; 25: 1377-1385. http://dx.doi.org/10.1093/ carcin/bgh 122

[45] ALBRECHTSSON E, OHLSSON B, AXELSON J. The expression of retinoic acid receptors and the effects in vitro by retinoids in human pancreatic cancer cell lines. Pancreas 2002; 25: 49-56. http://dx.doi.org/10.1097/00006676-200207000$\underline{00013}$

[46] YEN W-C, PRUDENTE RY, LAMPH WW. Synergistic effect of a retinoid $\mathrm{X}$ receptor-selective ligand bexarotene (LGD1069, Targretin) and paclitaxel (Taxol) in mammary carcinoma. Breast Cancer Res Treat 2004; 88: 141-148. http:// dx.doi.org/10.1007/s10549-004-1426-5

[47] RENDI MH, SUH N, LAMPH WW, KRAJEWSKI S, REED JC et al. The selective estrogen receptor modulator arzoxifene and the rexinoid LG100268 cooperate to promote transforming growth factor beta-dependent apoptosis in breast cancer. Cancer Res 2004; 64: 3566-3571. http://dx.doi. org/10.1158/0008-5472.CAN-04-0234

[48] FU J, DING Y, HUANG D, LI H, CHEN X. The retinoid X receptor-selective ligand, LGD1069, inhibits tumor-induced angiogenesis via suppression of VEGF in human non-small cell lung cancer. Cancer Lett 2007; 248: 153-163. http://dx.doi. org/10.1016/j.canlet.2006.06.012

[49] MERK D, STEINHILBER D, SCHUBERT-ZSILAVECZ M. Medicinal chemistry of farnesoid $\mathrm{X}$ receptor ligands: from agonists and antagonists to modulators. Future Med Chem 2012; 4: 1015-1036. http://dx.doi.org/10.4155/fmc.12.47

[50] FIORUCCI S, MENCARELLI A, DISTRUTTI E, ZAMPELLA A. Farnesoid X receptor: from medicinal chemistry to clinical applications. Future Med Chem 2012; 4: 877-891. http:// dx.doi.org/10.4155/fmc.12.41

[51] MARAN RR, THOMAS A, ROTH M, SHENG Z, ESTERLY $\mathrm{N}$ et al. Farnesoid $\mathrm{X}$ receptor deficiency in mice leads to increased intestinal epithelial cell proliferation and tumor development. J Pharmacol Exp Ther 2009; 328: 469-477. http://dx.doi.org/10.1124/jpet.108.145409

[52] MODICA S, MURZILLI S, SALVATORE L, SCHMIDT DR, MOSCHETTA A. Nuclear bile acid receptor FXR protects against intestinal tumorigenesis. Cancer Res 2008; 68: 9589-9594. http://dx.doi.org/10.1158/0008-5472.CAN-08$\underline{1791}$

[53] PENG Z, RAUFMAN JP, XIE G. Src-mediated cross-talk between farnesoid $\mathrm{X}$ and epidermal growth factor receptors inhibits human intestinal cell proliferation and tumorigenesis. PLoS One 2012; 7: e48461. http://dx.doi.org/10.1371/journal. pone. 0048461

[54] XU Y, WATANABE T, TANIGAWA T, MACHIDA H, OKAZAKI $\mathrm{H}$ et al. Bile acids induce $\mathrm{cdx} 2$ expression through the farnesoid $\mathrm{x}$ receptor in gastric epithelial cells. J Clin Biochem Nutr 2010; 46: 81-86. http://dx.doi.org/10.3164/ jcbn.09-71 
[55] WANG YD, CHEN WD, WANG M, YU D, FORMAN BM et al. Farnesoid $\mathrm{X}$ receptor antagonizes nuclear factor kappaB in hepatic inflammatory response. Hepatology 2008; 48: 1632-1643. http://dx.doi.org/10.1002/hep.22519

[56] DE GOTTARDI A, DUMONCEAU JM, BRUTTIN F, VONLAUFEN A, MORARD I et al. Expression of the bile acid receptor FXR in Barrett's esophagus and enhancement of apoptosis by guggulsterone in vitro. Mol Cancer 2006; 5: 48. http://dx.doi.org/10.1186/1476-4598-5-48

[57] LOWE LC, SENARATNE SG, COLSTON KW. Induction of apoptosis in breast cancer cells by apomine is mediated by caspase and p38 mitogen activated protein kinase activation. Biochem Biophys Res Commun 2005; 329: 772-779. http:// dx.doi.org/10.1016/j.bbrc.2005.02.032 